\title{
Decreased Cholesteryl Ester Transfer Protein (CETP) mRNA and Protein and Increased High Density Lipoprotein Following Lipopolysaccharide Administration in Human CETP Transgenic Mice
}

\author{
Lorì Masucci-Magoulas, * Philippe Moulin, * Xian Cheng Jiang, ${ }^{*}$ Hugh Richardson, * Annemarie Walsh, ${ }^{\star}$ Jan L. Breslow, ${ }^{\star}$ \\ and Alan Tall* \\ *Division of Molecular Medicine, Department of Medicine, College of Physicians and Surgeons, Columbia University, New York 10032; \\ and ${ }^{\ddagger}$ Laboratory of Biochemical Genetics, Rockefeller University, New York 10021
}

\begin{abstract}
The plasma cholesteryl ester transfer protein (CETP) mediates the exchange of HDL cholesteryl esters (CE) and VLDL triglycerides leading to catabolism of HDL. There is some evidence that HDL ameliorates the toxicity of LPS, and LPS is known to influence several enzymes affecting HDL metabolism. Therefore, the effects of LPS on CETP and plasma lipoproteins were examined in human CETP transgenic mice. Administration of LPS to mice expressing a CETP transgene linked to its natural flanking sequences (NFRCETP Tg) resulted in a rapid marked decrease in hepatic CETP mRNA and plasma CETP concentration. Corticosteroid injection produced a similar decrease in hepatic CETP mRNA and adrenalectomy abolished this response to LPS. LPS caused disproportionate reductions in plasma CETP activity compared to mass, and was found to be a potent inhibitor of CETP activity when added directly to plasma. LPS was injected into mice expressing $(A)$ a human apoAI transgene, $(B)$ apoA-I and NFR-CETP transgenes, or $(C)$ apoA-I and LPS-inducible metallothionein promoter-driven CETP transgenes, producing $(A)$ minimal changes in HDL cholesterol, $(B)$ decreased plasma CETP and increased HDL cholesterol, and $(C)$ increased plasma CETP and decreased HDL cholesterol. Thus, LPS administration produces a profound decrease in hepatic CETP mRNA, primarily as a result of adrenal corticosteroid release. The decrease in plasma CETP activity after LPS administration may reflect both this effect as well as a direct interaction between CETP and LPS. The decrease of CETP in response to LPS has major effects on HDL levels, and may represent an adaptive response to preserve or increase HDL and thereby modify the response to LPS. (J. Clin. Invest. 1995. 95:15871594.) Key words: cholesteryl ester transfer protein - lipopolysaccharide $\cdot$ transgenic mice $\cdot$ corticosteroid $\bullet$ high density lipoproteins
\end{abstract}

Address correspondence to Alan Tall, Division of Molecular Medicine, Department of Medicine, Columbia University, $630 \mathrm{~W}$. 168th Street, New York, NY 10032. Phone: 212-305-4899; FAX: 212-305-5052. Philippe Moulin's present address is INSERM, Unite 63, 69675 Bron Cedex, France.

Received for publication 18 April 1994 and in revised form 22 November 1994.

J. Clin. Invest.

(C) The American Society for Clinical Investigation, Inc. 0021-9738/95/04/1587/08 $\$ 2.00$

Volume 95, April 1995, 1587-1594

\section{Introduction}

The metabolism of HDL is regulated, in part, by the activities of lipases and lipid transfer proteins (1). Cholesteryl esters, generated in HDL by lecithin:cholesterol acyltransferase, are exchanged with triglycerides of VLDL, as a result of the activity of cholesteryl ester transfer protein (CETP) ${ }^{1}$. The subsequent activity of hepatic lipase on triglyceride-enriched HDL results in a decrease in HDL size and catabolism of the major apoliprotein of HDL, apoA-I (2). In a striking demonstration of the interaction of hypertriglyceridemia with cholesteryl ester transfer processes, hypertriglyceridemic apoC-III transgenic mice show profound reductions in HDL cholesterol and apoA-I when crossed with human CETP/apoA-I transgenic mice, to produce apoA-I/CETP/apoC-III transgenic mice (3). In addition to plasma triglyceride concentration, effective plasma CETP activity is also influenced by changes in CETP concentration, such as those resulting from changes in dietary cholesterol or probucol therapy $(4,5)$.

HDL is thought to mediate the reverse transport of cholesterol from peripheral tissues to the liver (6). In addition to this well-known role, Ulevitch et al. (7) have suggested another, novel function for HDL, namely to bind bacterial lipopolysaccharide (endotoxin) and thereby to modulate its biological effects. The binding of endotoxin to HDL can prevent endotoxininduced death (8). Harris et al. (9) have shown that VLDL and chylomicrons can also bind endotoxin, and protect mice against endotoxin-induced death. However, the potency of HDL appeared to be greater than that of other lipoproteins (9), and the molar concentrations of HDL in plasma are usually higher than other lipoproteins. Another role of HDL may be to provide cholesterol for adrenal corticosteroid synthesis (10-12), a function that could be particularly important during stress (13).

The purpose of the present study was to examine the possible regulation of CETP gene expression in response to LPS administration. We suspected that CETP might be altered by LPS, since LPS has profound effects on lipoprotein metabolism and is known to regulate lipoprotein lipase and LCAT activities $(14,15)$. Mice do not normally have significant plasma cholesteryl ester transfer activity. Human CETP transgenic mice expressing a CETP minigene linked to the inducible metallothionein promoter (mT-CETP Tg mice) show reduced HDL levels following zinc induction. Human CETP transgenic mice expressing a CETP transgene linked to its natural flanking sequences (NFR-Tg mice) express plasma CETP levels and activ-

1. Abbreviations used in this paper: apo, apoliprotein; CETP, cholesteryl ester transfer protein; mT, metallothionein; NFR, natural flanking sequence; $\mathrm{Tg}$, transgenic mice. 
ities similar to human, show reduced HDL, and display a humanlike distribution of CETP mRNA $(16,17)$. These two types of CETP transgenic mice were therefore used to explore LPS responses.

\section{Methods}

Transgenic mice. Studies have been conducted with five different varieties of transgenic mice. (a) NFR-CETP transgenic mice: these mice express a human CETP transgene including $3.2 \mathrm{~kb}$ and $2 \mathrm{~kb}$ of the $5^{\prime}$ and the 3 ' flanking region, respectively, (16). Studies were carried out with two different lines of NFR-CETP mice, (5171 and 5203) (which show twofold differences in plasma CETP concentration [17]), with similar results in both lines. $(b)$ mT-CETP transgenic mice: these mice express the human CETP transgene under the control of the mouse metallothionein promoter (18). (c) Human apo A-I transgenic mice: these express the human apoA-I gene (19). (d) NFR-CETP/apo A-I transgenic mice: these mice contain both human CETP and human apo A-I transgenes, derived by cross-breeding. (e) mT-CETP/apo A-I transgenic mice: these mice express both the human mT-CETP and human apo A-I transgenes (20). All animals studied were of mixed genetic background (C57BL6xCBA).

Male and female heterozygote transgenic mice or their nontransgenic littermates were used in all experiments. They had free access to food and distilled water. They were fed a regular chow diet (Purina Lab rodent chow 5001; Ralston Purina Co., St. Louis, MO) or a high fat, high cholesterol diet ( $15 \%$ fat, $1.25 \%$ cholesterol, $0.5 \%$ sodium cholate; TD 90221; Teklad Premier Lab Diets, Madison, WI). The response to LPS was similar on both diets. Lipopolysaccharide (Escherichia coli 0127:B8) was obtained from Difco Laboratories Inc. (Detroit, MI) and suspended in sterile saline. Stock LPS $(10 \mathrm{mg} / \mathrm{ml})$ was sonicated before dilution, using a sonifier (Branson 450; Branson Ultrasonics Corp., Dambury, CT) (output $6,60 \%$ duty cycle) for $30-45 \mathrm{~s}$, and just before use. To study the response to LPS or corticosteroids, mice were injected with a single dose of LPS or cortisone acetate intraperitoneally and killed 4,8 , or $24 \mathrm{~h}$ later. The mice appeared to be in a normal state of health after $25 \mu \mathrm{g}$ LPS injection. Some of the mice did show some physical signs of endotoxin shock after receiving $200 \mu \mathrm{g}$ LPS.

NFR-CETP mice were anesthetized with $2.5 \%$ Avertin (Aldrich Chemical Co., Milwaukee, WI) intraperitoneally as described (21) and adrenalectomized by a standard procedure (22). Sham-operated animals were subjected to the same surgical manipulation except the adrenal glands were not removed. All mice were allowed to recover $6 \mathrm{~d}$ and normal saline was substituted for drinking water.

RNAse protection assay and nuclear run-on analysis. Total RNA (40-50 $\mu \mathrm{g})$, extracted from liver immediately after death was analyzed for CETP mRNA by a solution hybridization-RNase protection assay using a riboprobe specific for human CETP mRNA (18). All CETP mRNA values were normalized to $\beta$-actin for each treatment and individual timepoint. The $\beta$-actin probe was included in the solution hybridization. Labeled CETP transcripts from liver nuclei obtained after an in vitro elongation reaction were analyzed as previously described (16).

Measurement of plasma CETP concentration and activity. Plasma CETP concentration was determined by solid phase RIA as described (23) and plasma CETP activity was measured in diluted plasma using radiolabeled HDL and excess LDL (19).

Plasma lipid and lipoprotein measurements. Lipoprotein profiles were obtained by fast protein liquid chromotography of plasma. Pooled aliquots $(200 \mu \mathrm{l})$ of plasma were loaded through a 200- $\mu \mathrm{l}$ Teflon sample loop on a Superose 6 HR 10/30 column (fast protein liquid chromatography system; Pharmacia LKB Biotechnology Inc., Piscataway, NJ). After elution of the initial $5.5 \mathrm{ml}, 30$ fractions of $0.7 \mathrm{ml}$ were collected at a flow rate of $0.35 \mathrm{ml} / \mathrm{min}$. Cholesterol (free and total) and triglycerides were assayed by enzymatic method using commercial kits (Wako Bioproducts, Richmond, VA).

Statistical analysis. Differences between groups were tested by oneway ANOVA or Student's $t$ test, where appropriate. All analyses were

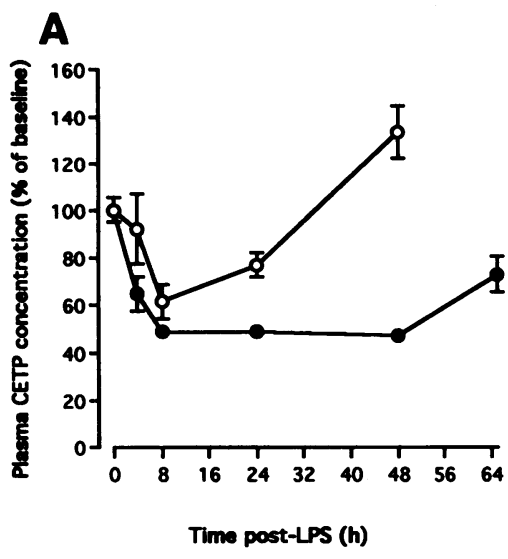

Figure 1. Plasma CETP concentration and CETP mRNA abundance in NFR-CETP transgenic mice (line 5203) treated with LPS ( $25 \mu \mathrm{g}$ or 200 $\mu \mathrm{g}) . A$ shows the change in plasma CETP concentration after LPS ( $25 \mu \mathrm{g}$, open circles; $200 \mu \mathrm{g}$, closed circles). Plasma CETP concentration was determined by RIA. The values for CETP concentration are means \pm SEM for mice killed at each time point, $25 \mu \mathrm{g}$ LPS ( $n$

8

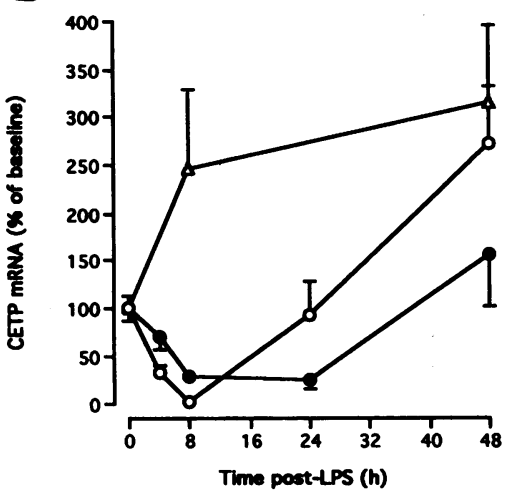

$=4-5$ mice $)$ and $200 \mu \mathrm{g}$ LPS ( $n=3-4$ mice).

For the $25-\mu \mathrm{g}$ dose, the 8,24 and $48 \mathrm{~h}$ values are significantly different to $0 \mathrm{~h}(P \leq 0.03)$. For the $200-\mu \mathrm{g}$ dose the $4,8,24$, and $48 \mathrm{~h}$ values are significantly different to $0 \mathrm{~h}$ $(P \leq 0.03)$. Baseline plasma CETP concentrations were $3.23 \pm 0.44$ $\mu \mathrm{g} / \mathrm{ml}(25 \mu \mathrm{g} \mathrm{LPS})$ and $3.72 \pm 0.17 \mu \mathrm{g} / \mathrm{ml}(200$ $\mu$ g LPS). $B$ shows the abundance of hepatic

(circles) and splenic (triangles) CETP mRNA after LPS injection (25 $\mu \mathrm{g}$, open circles or $200 \mu \mathrm{g}$, closed circles). CETP mRNA abundance was determined by RNAse protection assay. The human CETP riboprobe was hybridized with $50 \mu \mathrm{g}$ of total RNA from liver or spleen The values for CETP mRNA are means \pm SEM for mice, killed at each time point. For liver CETP mRNA using $25 \mu \mathrm{g}$ LPS, the 4,8 , and 48 $\mathrm{h}$ values are significantly different to $0 \mathrm{~h}(P \leq 0.006)$; using $200 \mu \mathrm{g}$ LPS, the 8 and $24 \mathrm{~h}$ values are also significantly different to $0 \mathrm{~h}$ ( $P$ $\leq 0.01)$. The spleen CETP mRNA ( $25 \mu \mathrm{g}$ LPS $) 48 \mathrm{~h}$ value is significantly different to $0 \mathrm{~h}(P \leq 0.003)$.

performed with the statistics software (Blackwell Scientific Publications, Oxford, United Kingdom), significance levels given are those for the two-tailed test. Data are presented as mean \pm SEM.

\section{Results}

Changes in plasma CETP concentration and in hepatic CETP mRNA after lipopolysaccharide injection. To evaluate effects of LPS on CETP gene expression, LPS ( 25 or $200 \mu \mathrm{g}$ ) was injected into mice expressing a CETP transgene linked to its natural flanking sequences (NFR-CETP Tg mice). LPS injection resulted in a marked decrease in plasma CETP concentration with the maximum effect seen at $8 \mathrm{~h}$ (Fig. $1 \mathrm{~A}$ ). After the smaller dose of LPS, there was a gradual recovery of plasma CETP levels, followed by a rebound to levels significantly above baseline values at $48 \mathrm{~h}$ (Fig. 1 A, open circles). The larger dose of LPS resulted in a more sustained decrease in plasma CETP levels (Fig. $1 \mathrm{~A}$, closed circles). A dose-response experiment showed significant decreases in plasma 
Table I. Plasma CETP Concentration in Human CETP Transgenic Mice Treated with Increasing Doses of LPS

\begin{tabular}{lc}
\hline \multicolumn{1}{c}{ Treatment } & CETP concentration \\
\hline & $\mu \mathrm{g} / m l$ \\
Saline & $2.07 \pm 0.16$ \\
$0.25 \mu \mathrm{g} \mathrm{LPS}$ & $2.04 \pm 0.15$ \\
$2.5 \mu \mathrm{g} \mathrm{LPS}$ & $1.59 \pm 0.07^{*}$ \\
$25 \mu \mathrm{g} \mathrm{LPS}$ & $1.26 \pm 0.08^{*}$ \\
$250 \mu \mathrm{g} \mathrm{LPS}$ & $1.41 \pm 0.22^{*}$ \\
$2,500 \mu \mathrm{g}$ LPS & $1.39 \pm 0.07^{*}$
\end{tabular}

NFR-CETP $\mathrm{Tg}$ mice (line 5171, both male and female), maintained on a chow diet, were injected intraperitoneally with LPS. Blood was drawn $6 \mathrm{~h}$ after injection. Plasma CETP mass was determined by radioimmunoassay. Values are mean \pm SEM, $n=4-5$ animals per dose. $* P<0.03$ vs saline.

CETP concentration at LPS doses as low as $2.5 \mu \mathrm{g}$ with maximum effects at a $25-\mu \mathrm{g}$ dose (Table I).

LPS administration resulted in a rapid profound decrease in hepatic CETP mRNA, with a nadir at $8 \mathrm{~h}$ (Fig. $1 \mathrm{~B}$ ). For the smaller dose of LPS, this was followed by a rebound to levels significantly above baseline (Fig. $1 \mathrm{~B}$, open circles). For the larger dose of LPS the decrease in hepatic CETP mRNA was more prolonged (Fig. $1 \mathrm{~B}$, closed circles). Measurement of CETP mRNA in other organs showed a different pattern of response, exemplified by the changes in the spleen, where there was an increase in CETP mRNA, significantly above baseline at $48 \mathrm{~h}$ (Fig. $1 \mathrm{~B}$, triangles). Analysis of pooled samples of other organs (small intestine, kidney, and adipose tissue) showed a similar response to the spleen, i.e., a gradual rise in CETP mRNA to levels above baseline at $48 \mathrm{~h}$ (not shown).

Corticosteroid effects on CETP protein and mRNA in transgenic Mice. The effects of LPS are known to be mediated by cytokine or corticosteroid release (24-26). Corticosteroid therapy appears to decrease plasma CETP levels in humans (27). To see if changes in CETP levels could be induced by corticosteroids, NFR-CETP Tg mice were injected intraperitoneally with a low dose of cortisone $(20 \mu \mathrm{g} / \mathrm{g})$ or saline and hepatic CETP mRNA was measured $8 \mathrm{~h}$ later. There was a marked $(85 \%)$ decrease in the abundance of hepatic CETP mRNA compared to saline-treated controls (Fig. 2). The total hepatic RNA recovered from cortisone-treated mice was not significantly different to that from control mice $(7.0 \pm 3$ vs $5.2 \pm 2 \mathrm{mg}$ RNA per liver, respectively). A time course study $(0,4,8,24$, and $48 \mathrm{~h}, n=3$ or 4 at each time point $)$ showed that the maximum decrease in hepatic CETP mRNA occurred $8 \mathrm{~h}$ after corticosteroid injection but revealed no significant increase in CETP mRNA in the liver or spleen at $48 \mathrm{~h}$ (not shown). Plasma CETP levels measured at 8 and $24 \mathrm{~h}$ after cortisone injection showed decreases of $21 \pm 14 \%(n=12, \mathrm{NS})$ and $15 \pm 6 \%(n=10, P<0.03)$ at 8 and $24 \mathrm{~h}$, respectively.

The changes in hepatic CETP mRNA and plasma CETP levels after cortisone administration suggest that part of the response to LPS may be mediated by adrenal corticosteroid release. To address this issue directly LPS $(25 \mu \mathrm{g})$ was injected into mice previously subjected to adrenalectomy or sham operation. Sham-operated mice showed a significant decrease in plasma CETP concentration after LPS (Fig. 3). There was a

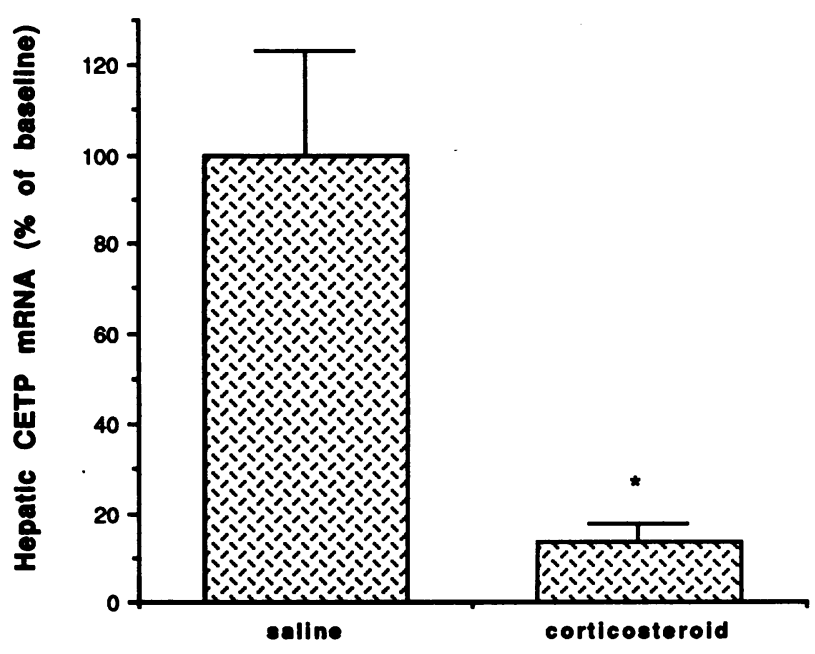

Treatment

Figure 2. Hepatic CETP mRNA abundance in NFR-CETP Tg mice after corticosteroid treatment. NFR-CETP Tg mice (line 5203) received a single injection of cortisone $(20 \mu \mathrm{g} / \mathrm{g})$ or saline. Hepatic CETP mRNA abundance was determined by RNAse protection assay, and is expressed as a percentage of the mean value of control 5203 mice, injected with saline and killed at the same time. The human CETP riboprobe was hybridized with $50 \mu \mathrm{g}$ of liver total RNA ( $n=4-5$ mice for each condition). Total liver weight was not significantly different in corticosteroid compared to saline treated mice $(1.4 \pm 0.2 \mathrm{~g}$ vs $1.04 \pm 1.0 \mathrm{~g}$, respectively). ${ }^{*} P<0.02$ vs $8 \mathrm{~h}$ saline.

smaller, insignificant decrease in plasma CETP levels after LPS in adrenalectomized mice.

The response of hepatic CETP mRNA to LPS was also compared in sham-operated or adrenalectomized mice (Fig. 4). LPS produced a marked decrease in hepatic CETP mRNA in sham-operated mice (data for individual mice shown in Fig. 4). This response to LPS was abolished by adrenalectomy (Fig.

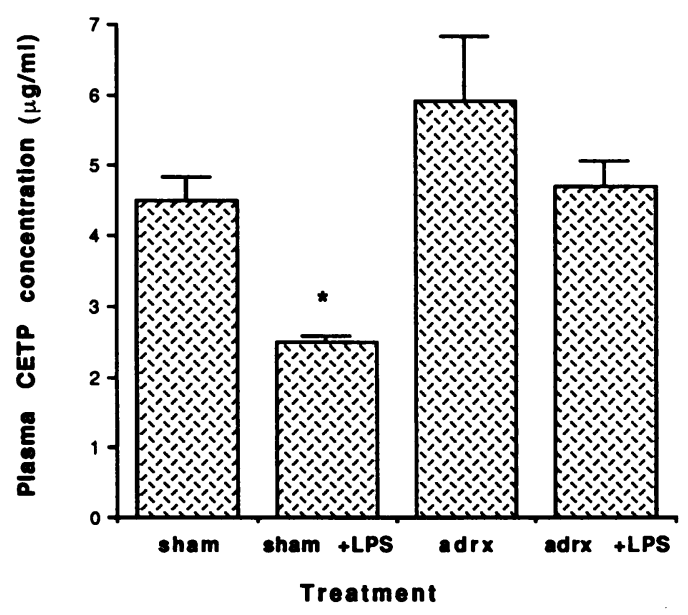

Figure 3. Plasma CETP concentration in adrenalectomized ( $a d r x)$ and sham-operated NFR-CETP Tg mice treated with saline or LPS $(25 \mu \mathrm{g})$. CETP Tg mice (line 5203) were operated on, maintained on a chow diet and saline drinking water for $6 \mathrm{~d}$, then treated with saline or LPS intraperitoneally as indicated. Plasma was obtained $8 \mathrm{~h}$ after injection. Values are mean \pm SEM from 6 to 10 mice per group. ${ }^{*} P<0.001$ vs all groups. 


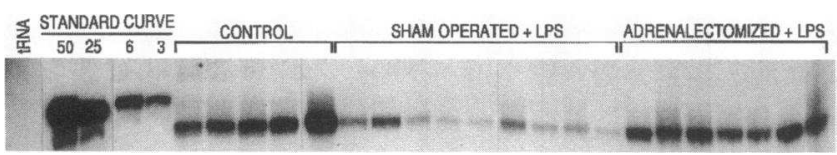

Figure 4. RNAse protection assay showing hepatic CETP mRNA abundance in individual adrenalectomized and sham-operated NFR-CETP $\mathrm{Tg}$ mice treated with LPS. CETP Tg mice (line 5203) were treated with a low dose $(25 \mu \mathrm{g})$ of LPS and killed at $8 \mathrm{~h}$. The negative control ( $t R N A)$ and standards $(50,25,6$, and 3 pg of sense CETP RNA) were also hybridized with the human CETP riboprobe. Shown is the protected fragment in $40 \mu \mathrm{g}$ total liver RNA from individual mice either adrenalectomized (LPS treated, $n=7$ ), sham-operated (LPS treated, $n=9$ ), and nonoperated control NFR-CETP transgenic mice $(n=5)$.

4). Quantitation of the CETP mRNA response indicated an 85\% reduction in CETP mRNA in response to LPS ( $P$ $<0.0002$ ), with significantly higher levels of hepatic CETP mRNA in adrenalectomized mice $(P<0.001)$, and no significant difference between adrenalectomized mice and noninjected controls. These results indicate that the effects of LPS on hepatic CETP mRNA are primarily mediated by adrenal corticosteroid release.

To determine the mechanism of decrease in CETP mRNA in response to cortisone, run-on assays were performed using nuclei prepared from NFR-CETP Tg mice treated with placebo or cortisone (Table II). These experiments showed no significant change in newly initiated transcripts using liver nuclei prepared $3 \mathrm{~h}$ after cortisone injection $(20 \mu \mathrm{g} / \mathrm{g})$. An assessment of hepatic CETP mRNA levels in the same experiments confirmed a marked decrease, as in earlier experiments. These results suggest that the decrease in CETP mRNA after cortisone administration is not due to decreases in CETP gene transcriptional rate.

Plasma lipid and lipoprotein changes in response to LPS in CETP transgenic mice. Plasma lipoprotein responses were characterized in more detail in mice receiving the higher doses of LPS $(200 \mu \mathrm{g})$, with a view to understanding how the changes in plasma CETP might modulate the toxicity of LPS. LPS was injected into apoA-I, NFR-CETP/apoA-I, and mT-CETP/ apoA-I transgenic mice. ApoA-I transgenic mice were used since the effects of CETP on HDL are larger in CETP/apoA-I

Table II. Run-on Assay Using Liver Nuclei to Measure CETP Transcripts

\begin{tabular}{lcc}
\hline & $\begin{array}{c}\text { Specific CETP } \\
\text { transcripts }\end{array}$ & CETP/ $\beta$-actin or GADPH ratio \\
\hline & $(O D U)$ & \\
Saline & $722 \pm 383$ & $1.2 \pm 0.40$ \\
Corticosteroid & $659 \pm 319$ & $1.8 \pm 0.70$ \\
\hline
\end{tabular}

Mice were treated with $20 \mu \mathrm{g} / \mathrm{g}$ cortisone acetate or saline intraperitoneally and killed at $3 \mathrm{~h}$. Liver nuclei were prepared and an in vitro elongation was carried out, as previously described (16). Values represent mean \pm SEM for specific hybridization of CETP transcripts for five independent experiments, using pooled nuclei from two to three mice per treatment group. All values are arbitrary optical density units which were subtracted from background $\mathrm{KS}+$ bluescript vector (represening $10-15 \%$ of the signal). These values were obtained by scanning autoradiograms of nitrocellulose filter prepared as described (16).

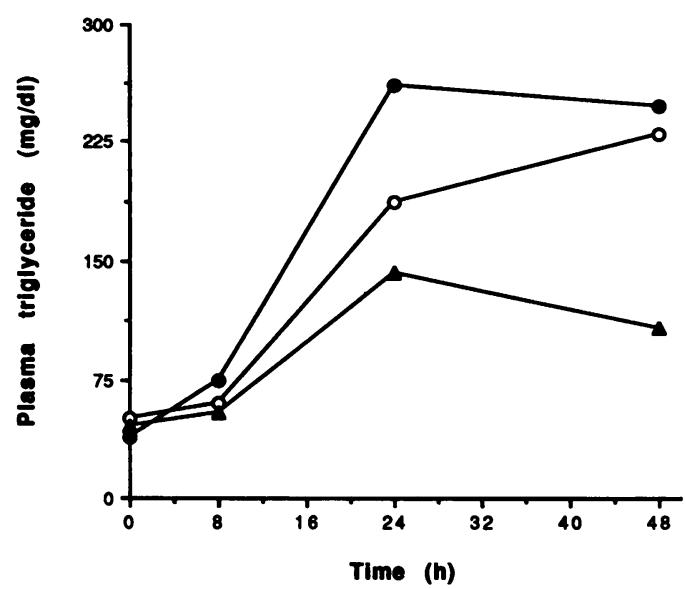

Figure 5. Change in plasma triglyceride concentration in different lines of transgenic mice after LPS treatment. A 200- $\mu$ g dose of LPS was injected intraperitoneally into human apoA-I (triangles), NFR-CETP/ apoA-I (open circles), and mT-CETP/apoA-I mice (closed circles). All values are means from at least six individual mice. Values are significantly different $(P<0.001)$ for both 24 and $48 \mathrm{~h}$ vs baseline value in all groups.

transgenic mice than in CETP transgenic mice (20). The mTCETP transgenic mice were also studied since the $\mathrm{mT}$ promoter is upregulated by corticosteroid and LPS $(28,29)$, offering a contrasting response to that in NFR-CETP transgenic mice. As in earlier studies (Fig. 1), plasma CETP concentration was decreased after LPS in the NFR-CETP/apoA-I mice (not shown). By contrast, CETP mass and activity were markedly increased in mT-CETP/apoA-I mice (no change at $8 \mathrm{~h}$, but a 5.5-fold increase at $24 \mathrm{~h}$ compared to baseline), reflecting the inducibility of the $\mathrm{mT}$ promoter. Hepatic CETP mRNA was also markedly increased in MT-CETP mice treated with LPS (not shown). These results reflect the inducibility of the $\mathrm{mT}$ promoter, which presumably overcomes any residual effect of corticosteroid to decrease CETP mRNA on a posttranscriptional level at $24 \mathrm{~h}$.

Plasma triglyceride levels rose after LPS administration, as expected (Fig. 5). For all groups plasma triglyceride levels were significantly elevated at 24 and $48 \mathrm{~h}$ compared to baseline $(P<0.001)$. However, the mT-CETP/apoA-I group seemed to show greater elevations in triglyceride than the apoA-I group $(P<0.06)$, perhaps indicating a more marked biological effect of LPS.

There were dramatic differences in the response of the plasma lipoproteins in animals of different genotype. At baseline, the NFR-CETP/apoA-I and mT-CETP/apoA-I transgenic mice showed reduced levels of HDL cholesterol, compared to the apoA-I transgenic animals (Fig. 6, top). The reduction in HDL was greater in mT-CETP/apoA-I mice than in NFRCETP/apoA-I mice due to their higher CETP level (2.5 vs 1.2 $\mu \mathrm{g} / \mathrm{ml}$, respectively). $24 \mathrm{~h}$ after LPS administration there was a slight decrease in HDL cholesterol in the apoA-I transgenic mice (Fig. 6, bottom). There was a marked increase in HDL cholesterol in the NFR-CETP/apoA-I transgenic mice, to levels approximating those in the apoA-I transgenic mice (Fig. 6, bottom), whereas the MT-CETP/apoA-I mice showed a further decrease in HDL cholesterol. Changes in VLDL cholesterol were inversely related to the HDL responses, i.e., VLDL choles- 


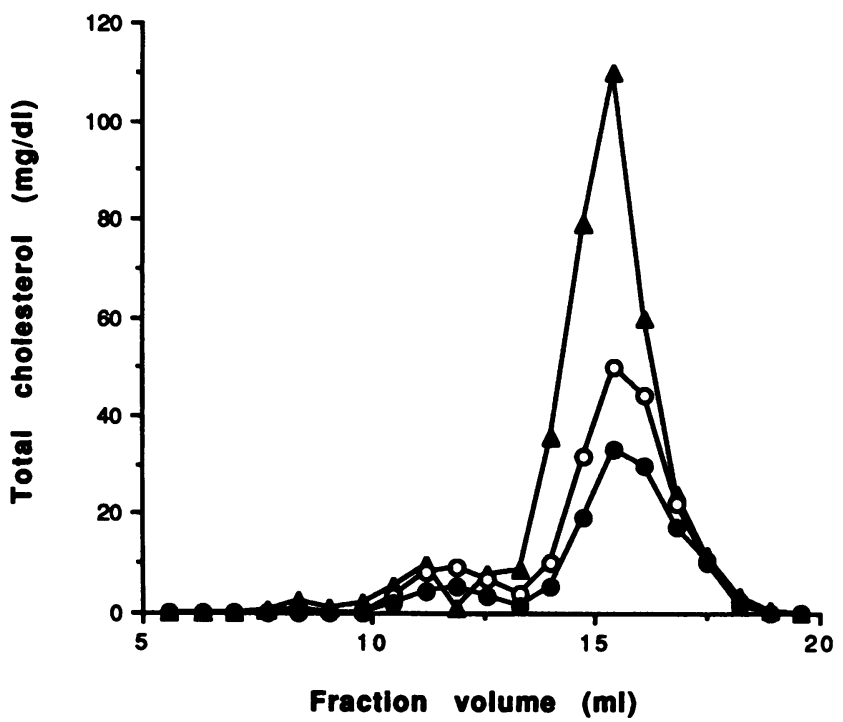

24 h post-LPS

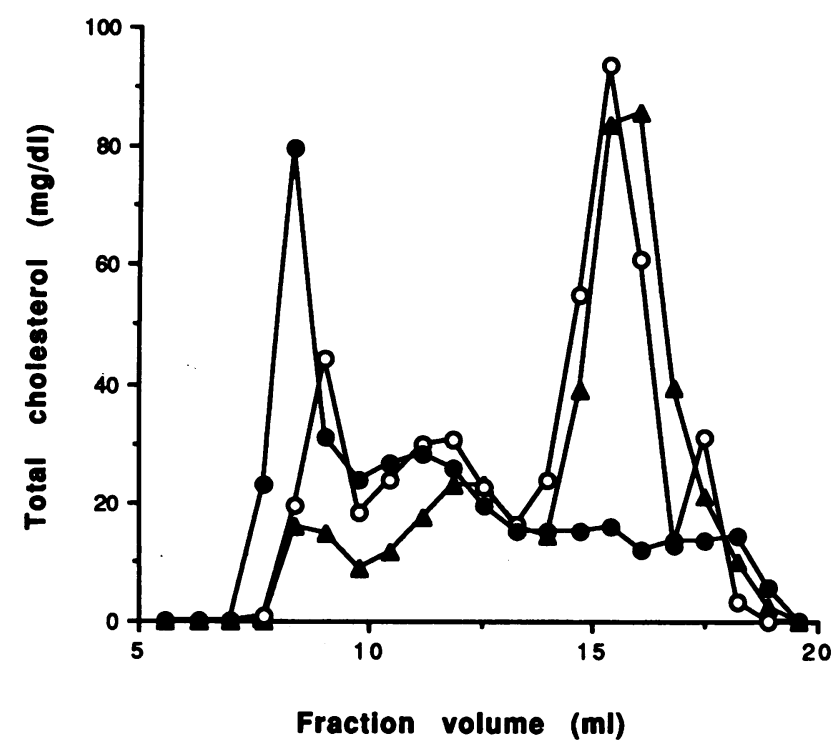

Figure 6. Concentration of total cholesterol in plasma lipoproteins of different lines of CETP transgenic mice after LPS treatment. Top panel shows apoA-I (triangles), NFR-CETP/apoA-I (open circles), and mTCETP/apoA-I (closed circles) mice after saline injection. Bottom panel shows apoA-I (triangles), NFR-CETP/apoA-I (open circles), and mTCETP/apoA-I (closed circles) mice $24 \mathrm{~h}$ after intraperitoneal LPS (200 $\mu \mathrm{g})$. Fast protein liquid chromatography was performed with $200 \mu \mathrm{l}$ of pooled plasma from 4 to 6 mice per treatment group.

terol was most increased in $\mathrm{mT}$-CETP/apoA-I mice $>$ NFRCETP/apoA-I mice $>$ apo A-I mice. These results are consistent with increased CETP activity in the mT-CETP/apo A-I mice, but decreased activity in the NFR-CETP/apoA-I mice.

The effects of LPS on HDL cholesterol in NFR-CETP Tg mice were larger than anticipated (Fig. 6), since in other models (rabbits injected with CETP mAb) CETP inhibition of $>80 \%$ was needed to produce a doubling of HDL-cholesterol (30), and the decrease in CETP mass $24 \mathrm{~h}$ after LPS was only $\sim 25 \%$ in the experiments on Fig. 6 . Thus, changes in plasma CETP

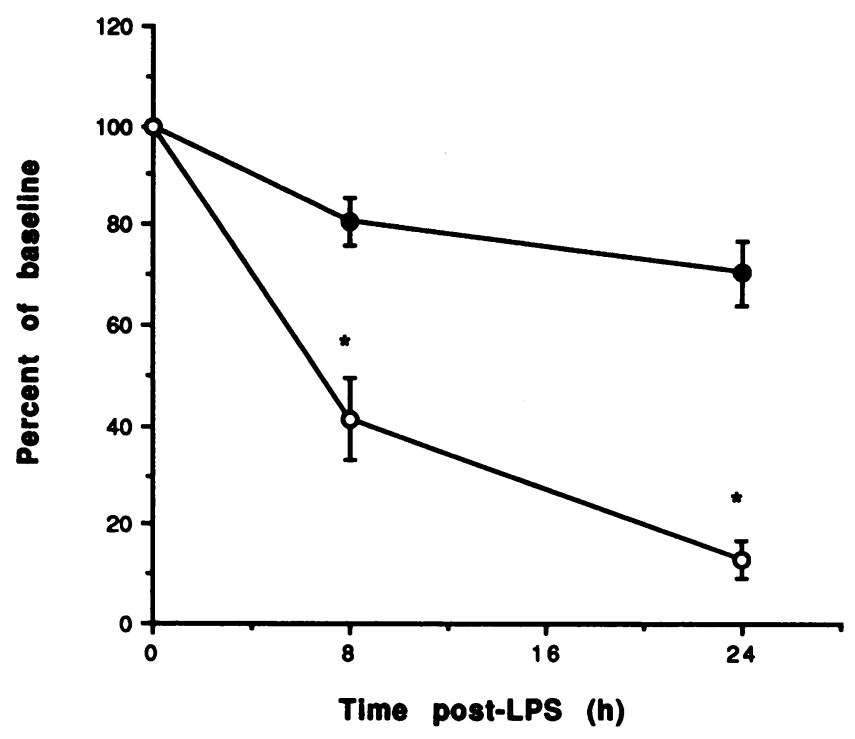

Figure 7. Change in plasma CETP activity and concentration in NFRCETP Tg mice after LPS injection. NFR-CETP Tg mice (line 5203) were injected with LPS $(200 \mu \mathrm{g})$ intraperitoneally. Plasma CETP activity (open circles) was measured in diluted plasma using an in vitro isotopic assay. Plasma CETP concentration (closed circles) was determined by RIA. CETP activity and concentration are expressed as percentage of values in saline-treated controls. Baseline plasma CETP concentration was $3.0 \pm 0.2 \mu \mathrm{g} / \mathrm{ml}$ and baseline plasma CETP activity was $388 \mathrm{cpm}$ transferred/h per $\mu \mathrm{l}$ plasma. ${ }^{*} P<0.01$ activity vs concentration.

activity were compared to those in CETP mass. In NFR-CETP Tg mice receiving $200 \mu \mathrm{g}$ LPS, there was a disproportionate decrease in plasma CETP activity compared to plasma CETP mass (Fig. 7). Expressed as a percentage of baseline, plasma CETP activity reductions were significantly greater than mass reductions $(P<0.02)$. By contrast, plasma CETP activity and mass measurements were found to be parallel after corticosteroid injection (not shown). To examine the possibility that LPS might directly inactivate CETP, LPS was added to mouse plasma and CETP activity was assayed. LPS was found to be a potent inhibitor of CETP activity (Fig. 8). Since the activity assay uses precipitation of lipoproteins to separate HDL from apoB-containing particles, experiments were conducted to ensure that the apparent loss of activity was not due to altered lipoprotein precipitability. These experiments confirmed that LPS did not alter the measured activity of CETP when added at the end of the assay, showing that the observed inhibition was not an artifact of altered lipoprotein precipitability (Table III). The inhibitory effects of LPS could be overcome by increasing substrate (HDL) concentrations in the assay (not shown). More detailed dose-response studies at lower LPS concentrations, carried out in the linear range of the assay, indicated that the $\mathrm{IC}_{50}$ was $\sim 1 \mu \mathrm{g}$ LPS $(1.3 \mu \mathrm{M})$ when LPS was added to plasma of line 5171 mice, and $\sim 3 \mu \mathrm{g}$ LPS $(3.75 \mu \mathrm{M})$ when added to plasma of the higher expressing line 5203. The higher $\mathrm{IC}_{50}$ in plasma with higher CETP concentration is consistent with a direct interaction between CETP and LPS.

\section{Discussion}

LPS administration caused a profound decrease in hepatic CETP mRNA, decreased plasma CETP, and increased HDL in mice 


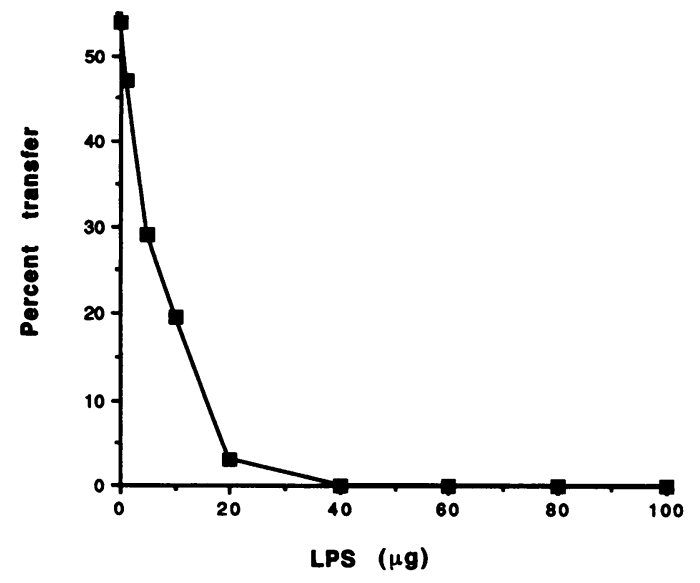

Figure 8. The effect of LPS on CETP activity in vitro. The CETP activity assay was performed by isotopic assay using $2 \mu \mathrm{l}$ of mouse plasma (containing $13 \mathrm{ng}$ CETP) with added human VLDL + LDL ( $100 \mu \mathrm{g}$ cholesterol), and 10,000 cpm of human HDL ( $9 \mu \mathrm{g}$ cholesterol). LPS was diluted in sterile saline and added to the reaction mixture, in a total reaction vol of $80 \mu \mathrm{l}$ and incubated at $37^{\circ} \mathrm{C}$ for $3 \mathrm{~h}$. Apo $\mathrm{B}$-containing lipoproteins were precipitated with a heparin-manganese cocktail containing BSA.

expressing a CETP transgene linked to its natural flanking sequences. Similar responses were produced by corticosteroid treatment and the response to LPS was abolished in adrenalectomized mice, indicating that the effects of LPS on hepatic CETP mRNA are mediated primarily by adrenal corticosteroid release. This contributes to decreased plasma CETP levels after LPS administration, but there also appear to be additional effects of LPS to decrease plasma CETP mass and activity, probably reflecting direct interactions between CETP and LPS. In species expressing CETP, such as humans, the decrease in plasma CETP activity may help to preserve HDL levels after exposure to LPS. HDL may have protective effects in animals or humans exposed to LPS as a result of binding LPS; HDL may also help to maintain adrenal cholesterol stores.

In NFR-CETP Tg mice the LPS and corticosteroid-induced decrease in plasma CETP levels were mediated at least in part by marked decreases in hepatic CETP mRNA levels. Hepatic synthesis is thought to be the main source of plasma CETP in primates, and plasma CETP levels are well correlated with liver CETP mRNA levels (31). Thus, the decrease in hepatic CETP mRNA is a plausible mechanism to explain the decrease in plasma CETP in response to steroids.

Even though the decrease in hepatic CETP mRNA was equivalent after LPS or cortisone administration (compare with Figs. 1 and 2), cortisone produced more limited reductions in $8 \mathrm{~h}$ plasma CETP levels $(15-20 \%)$ than LPS $(40-60 \%)$, suggesting additional mechanisms producing the LPS effect, particularly at higher doses of LPS. These additional effects might be secondary to a direct interaction between CETP and LPS. LPS was found to be an inhibitor of CETP activity both in vitro and in vivo. LPS caused a disproportionate reduction in CETP activity compared to mass when injected into NFRCETP Tg mice, suggesting a direct action of LPS on CETP or its lipoprotein substrates. This was confirmed by addition of LPS to plasma. Dose-response experiments indicated that LPS concentrations of 1-4 $\mu \mathrm{M}$ can produce $50 \%$ inhibition of plasma CETP activity. Given efficient absorption of LPS into
Table III. Plasm CETP Activity with LPS Addition during Incubation or Precipitation

\begin{tabular}{llllr}
\hline & \multicolumn{2}{c}{$\begin{array}{c}\text { Average cpm in } \\
\text { supernatant }\end{array}$} & & CETP activity \\
\cline { 2 - 3 } \cline { 5 - 5 } & Control & + CETP & & (cpm transferred $2.5 \mathrm{~h}$ ) \\
\hline Without LPS & $3,025 \pm 41$ & $2,439 \pm 21$ & & $587 \pm 21$ \\
+ LPS in precipitation & $2,995 \pm 104$ & $2,458 \pm 71$ & & $537 \pm 70$ \\
+ LPS during incubation & $2,950 \pm 91$ & $3,113 \pm 54^{*}$ & & $-163 \pm 54$
\end{tabular}

CETP activity assay was measured by isotopic assay using $1 \mu \mathrm{l}$ of mouse plasma (containing $5 \mathrm{ng}$ CETP) or $1 \mu \mathrm{l}$ of Tris-saline-EDTA with added human VLDL + LDL (100 $\mu \mathrm{g}$ cholesterol) and human HDL (9 $\mu \mathrm{g}$ cholesterol; $10,000 \mathrm{cpm}$ in cholesteryl ester, $n=4)$. LPS $(7 \mu \mathrm{g})$ was diluted in sterile saline and added just before incubation or in the precipitation cocktail. The total reaction vol was 80 $\mu \mathrm{l}$ and the incubation was at $37^{\circ} \mathrm{C}$ for $2.5 \mathrm{~h}$. Values are expressed as the mean $\pm \mathrm{SEM}$ of $\mathrm{cpm}$ remaining in $1 \mathrm{ml}$ of superntant after precipitation of apo B-containing lipoproteins with heparin-manganese cocktail containing BSA. ${ }^{*} P$ $\leq 0.001$ vs without LPS, or LPS in precipitation.

plasma (32), the in vitro experiments predict that inhibitory effects would be anticipated at the higher doses of LPS used in this study $(200 \mu \mathrm{g})$, consistent with observed in vivo effects. CETP is related to a family of LPS-binding proteins, including the plasma lipopolysaccharide-binding protein and the neutrophil bactericidal permeability-increasing protein (33). There is a direct, high affinity interaction between pure CETP and LPS (Tobias, P., R. Ulevitich, P. Kussie, and A. Tall, unpublished observation ). LPS micelles in plasma might compete with HDL for CETP binding, leading to reduced activity and accelerated clearance of CETP from plasma.

The effect of corticosteroids on CETP mRNA was rapid and was not associated with any significant change in CETP gene transcription (Table II). Although there was considerable imprecision in this assay, in earlier studies using the same assay conditions we were readily able to detect an increase in CETP gene transcription, mediating a fourfold increase in hepatic CETP mRNA in response to increased dietary cholesterol (16). Thus, we conclude that the decrease in hepatic CETP mRNA in response to corticosteroids was due to a posttranscriptional mechanism, such as decreased processing or transport of nuclear transcripts, or decreased mRNA stability.

After lower dose LPS administration, an acute decrease in hepatic CETP mRNA abundance was followed by a gradual recovery then an overshoot to levels above baseline, with parallel effects on plasma CETP levels (Fig. 1). CETP mRNA in peripheral organs was also increased $48 \mathrm{~h}$ after LPS injection. The parallel increase in liver and peripheral organs at $48 \mathrm{~h}$ could indicate a common response to a plasma factor. An equivalent increase in hepatic and peripheral CETP mRNA was not produced by cortisone injection, indicating the factor was not corticosteroids. The gradual increase in hepatic and peripheral CETP mRNA is reminiscent of the increase in CETP gene expression in response to dietary hypercholesterolemia. One possible explanation for these findings is that the increase in CETP mRNA represents a response to the hyperlipidemia that develops in response to LPS (Fig. 6). The decrease in plasma CETP followed by a rebound suggests an acute inhibition of reverse cholesterol transport mediated by $\operatorname{CETP}(1,6)$, followed by a recovery phase in which reverse cholesterol transport is increased.

One of the earliest responses to endotoxin is an increase in 
plasma VLDL concentrations. This has been proposed to represent the mobilization of peripheral energy stores to fuel the body's response to the infectious challenge (34). The mechanisms of this response include both increased hepatic triglyceride production, as well as decreased lipolysis, with increased hepatic production representing the dominant mechanism at lower endotoxin doses $(35,36)$. However, since hypertriglyceridemia is usually associated with decreased HDL levels due to CETP-mediated lipid exchange (37), it might be anticipated that the hypertriglyceridemia would produce a decrease in HDL cholesterol concentration in animals with normal plasma CETP activity. The availability of both NFR-CETP Tg mice and mTCETP Tg mice allowed us to compare the lipoprotein responses to LPS in animals with opposite CETP responses to LPS. These studies showed marked increases in HDL cholesterol in the former group vs decreases in HDL cholesterol in the latter group (Fig. 6). After LPS injection, there were relatively minor changes in HDL cholesterol in the apoA-I transgenic mice. These observations suggest that the decrease in CETP could be a major mechanism for regulating HDL concentration during endotoxin shock.

Recently, it has been shown that human apoA-I Tg mice are more resistant to endotoxin than nontransgenic mice (32), reflecting the ability of HDL to bind LPS $(32,38)$. The downregulation of CETP in response to LPS increases HDL and may thus modify the biological response to LPS. The preservation of HDL may also help to maintain or increase adrenal corticosteroid synthesis during stress $(7,12)$. A role of HDL in adrenal physiology is suggested by the recent finding that apoA-I knockout mice have depleted adrenal cholesterol stores (Plump, A., and J. Breslow, unpublished results). By suppressing CETP and increasing HDL, adrenal corticosteroid release could provide a positive feedback mechanism to help ensure the provision of cholesterol for further corticosteroid synthesis. However, LPS bound to HDL can be taken up by the adrenal and probably contribute to adrenal hemorrhage in the Waterhouse-Friderichsen syndrome (39). Thus, the overall biological consequences of LPS binding by HDL are likely to be complex. The suppression of cytokine synthesis by LPS-mediated corticosteroid release is generally viewed as a counterregulatory mechanism to blunt the response to LPS (40). The decrease in plasma CETP and the resulting increase in HDL may be viewed as a further example of the homeostatic modulation of LPS effects by corticosteroids.

\section{Acknowledgments}

We thank Dr. Reginald Miller for his expert guidance in animal surgery.

This work was supported by National Institutes of Health grants HL-43165, 21006, 33714, and 32425.

\section{References}

1. Tall, A. R. 1990. Plasma high density lipoproteins: metabolism and relationship to atherogenesis. J. Clin. Invest. 86:379-384.

2. Newnham, H. H., and P. J. Barter. 1990. Synergistic effects of lipid transfers and hepatic lipase in the formation of very small high-density lipoproteins during incubation of human plasma. Biochim. Biophys. Acta. 1044:57-64.

3. Hayek, T., N. Azrolan, R. B. Verdery, A. Walsh, T. Chajek-Shaul, L. B. Agellon, A. R. Tall, and J. L. Breslow. 1993. Hypertriglyceridemia and cholesteryl ester transfer protein interact to dramatically alter high density lipoprotein levels, particle sizes, and metabolism: studies in transgenic mice. J. Clin. Invest. 92:1143-1152.

4. Quinet, E. M., L. B. Agellon, P. A. Kroon, Y. L. Marcel, Y.-C. Lee, M. E.
Whitlock, and A. R. Tall. 1990. Atherogenic diet increases cholesteryl ester transfer protein messenger RNA levels in rabbit liver. J. Clin. Invest. 85:357363.

5. McPherson, R., M. Hogue, R. W. Milne, A. R. Tall, and Y. L. Marcel 1991. Increase in plasma cholesteryl ester transfer protein during probucol treatment: relation to changes in high density lipoprotein composition. Arterioscler. Thromb. 11:476-481.

6. Glomset, J. A. 1973. The metabolic role of lecithin:cholesterol acyltransferase: perspectives from pathology. Adv. Lipid Res. 11:1-65.

7. Ulevitch, R. J., A. R. Johnston, and D. B. Weinstein. 1979. New function for high density lipoproteins. Their participation in intravascular reactions of bacterial lipopolysaccharides. J. Clin. Invest. 64:1516-1524.

8. Ulevitch, R. J., and A. R. Johnston. 1978. The modification of biophysica and endotoxic properties of bacterial lipopolysaccharides by serum. J. Clin. Invest. 62:1313-1324.

9. Harris, H. W., C. Grunfeld, K. R. Feingold, and J. H. Rapp. 1990. Human very low density lipoproteins and chylomicrons can protect against endotoxininduced death in mice. J. Clin. Invest. 86:696-702.

10. Munford, R. S., J. M. Andersen, and J. M. Dietschy. 1981. Sites of tissue binding and uptake in vivo of bacterial lipopolysaccharide-high density lipoprotein complexes. Studies in the rat and squirrel monkey. J. Clin. Invest. 68:1503-1513.

11. Andersen, J., and J. Dietschy. 1978. Relative importance of high and low density lipoproteins in the regulation of cholesterol synthesis in the adrenal gland, ovary, and testis of the rat. J. Biol. Chem. 253:9024-9032.

12. Glass, C., R. C. Pittman, M. Civen, and D. Steinberg. 1985. Uptake of high density lipoprotein associated apoprotein A-I and cholesteryl esters by 16 tissues of the rat in vivo and by adrenal cells and hepatocytes in vitro. J. Biol. Chem. 260:744-750.

13. Chedid, L., F. Boyer, and M. Saviard. 1951. Surrenales et infection. Ann. Inst. Pasteur (Paris). :213-233.

14. Kawakami, M., and A. Cerami. 1981. Studies in endotoxin-induced decrease in lipoprotein lipase activity. J. Exp. Med. 154:631-639.

15. Auerbach, B., and J. Parks. 1989. Lipoprotein abnormalities associated with lipopolysaccharide-induced lecithin: cholesterol acyltransferase and lipase deficiency. J. Biol. Chem. 264:10264-10270.

16. Jiang, X.-C., L. B. Agellon, A. Walsh, and J. L. Breslow. 1992. Dietary cholesterol increases transcription of the human cholesteryl ester transfer protein gene in transgenic mice. J. Biol. Chem. 90:1290-1295.

17. Jiang, X.-C., L. Masucci-Magoulas, J. Mar, A. Walsh, J. Breslow, and A. Tall. 1993. Down-regulation of mRNA for the low density lipoprotein receptor in transgenic mice containing the gene for human cholesteryl ester transfer protein: mechanism to explain accumulation of lipoprotein B particles. J. Biol. Chem 268:27406-27412.

18. Agellon, L. B., A. Walsh, T. Hayek, P. Moulin, X.-C. Jiang, S. A. Shelanski, J. L. Breslow, and A. R. Tall. 1991. Reduced high density lipoprotein cholesterol in human cholesteryl ester transfer protein transgenic mice. J. Biol. Chem. 266:10796-10801.

19. Walsh, A., Y. Ito, and J. L. Breslow. 1988. High levels of human apo lipoprotein A-I in transgenic mice result in increased plasma levels of small high density lipoprotein (HDL) particles comparables to human $\mathrm{HDL}_{3}$. J. Biol. Chem. 264:6488-6494.

20. Hayek, T. T. Chajek-Shaul, A. Walsh, L. B. Agellon, P. Moulin, A. R. Tall, and J. L. Breslow. 1992. An interaction between the human cholesteryl ester transfer protein (CETP) and apolipoprotein A-1 genes in transgenic mice results in a profound CETP-mediated depression of high density lipoprotein cholesterol levels. J. Clin. Invest. 90:505-510.

21. Papaionnou, V., and J. Fox. 1993. Efficacy of tribromoethanol anesthesia in mice. Lab. Anim. Sci. 43:189-192.

22. Cunliffe-Beamer, T. L. 1983. Biomethodology and surgical techniques. In The Mouse in Biomedical Research. H. L. Foster, J. D. Small, and J. G. Fox, editors. Academic Press, New York. 420 pp.

23. Marcel, Y. L., R. McPherson, M. Hogue, H. Czarnecka, Z. Zawadzki, P. K. Weech, M. E. Whitlock, A. R. Tall, and R. W. Milne. 1990. Distribution and concentration of cholesteryl ester transfer protein of normolipemic subjects. J. Clin. Invest. 85:10-17.

24. Loppinoq, H., P. Libby, M. Freudenberg, J. Krauss, J. Weckesser, and H. Mayer. 1990. Cytokine induction by lipopolysaccharide (LPS) corresponds to lethal toxicity and is inhibited by nontoxic rhodobacter capsulatus LPS. Infect. Immun. 58:3743-3750.

25. Beutler, B., I. Milsark, and A. Cerami. 1986. Passive immunization against cachectin/tumor necrosis factor protects mice from lethal effects of endotoxin. Science (Wash. DC). 229:869-871.

26. Baumann, H., C. Richards, and J. Gauldie. 1987. Interaction among hepatocyte-stimulating factors, interleukin-1, and glucocorticoids for regulation of acutephase plasma proteins in human hepatoma (HepG2) cells. J. Immunol. 139:41224128 .

27. Moulin, P., G. B. Appel, H. N. Ginsberg, and A. R. Tall. 1992. Increased concentration of plasma cholesteryl ester transfer protein in nephrotic syndrome: role in dyslipidemia. J. Lipid Res. 33:1817-1822.

28. Mayo, K. E., and R. D. Palmiter. 1981. Glucocorticoid regulation of 
metallothionein-1 mRNA synthesis in cultured mouse cells. J. Biol. Chem. 256:2621-2624.

29. Sobocinski, P., and W. Canterbury. 1982. Hepatic metallothionein induction in inflammation. Ann. NY Acad. Sci. 210:354-367.

30. Whitlock, M. E., T. L. Swenson, R. Ramakrishnan, M. T. Leonard, Y. L. Marcel, R. W. Milne, and A. R. Tall. 1989. Monoclonal antibody inhibition of cholesteryl ester transfer protein activity in the rabbit. Effects on lipoprotein composition and high density lipoprotein cholesteryl ester metabolism. J. Clin. Invest. 84:129-137.

31. Quinet, E. M., A. R. Tall, R. Ramakrishnan, and L. Rudel. 1991. Plasma lipid transfer protein as a determinant of the atherogenicity of monkey plasma lipoproteins. J. Clin. Invest. 87:1559-1566.

32. Levine, D. M., T. S. Parker, T. M. Donnelly, A. M. Walsh, and A. L. Rubin. 1993. In vivo protection against endotoxin by plasma high density lipoprotein. Proc. Natl. Acad. Sci. USA. 90:12040-12044.

33. Schumann, R. R., S. R. Leong, G. W. Flaggs, P. W. Gray, S. D. Wright, J. C. Mathison, P. S. Tobias, and R. J. Ulevitch. 1990. Structure and function of lipopolysaccharide binding protein. Science (Wash. DC). 249:1429-1431.

34. Beisel, W. R. 1977. Magnitude of the host nutritional responses to infection. Am. J. Clin. Nutr. 30:1236-1247.
35. Beutler, B., N. Mahoney, N. L. Trang, P. Pekala, and A. Cerami. 1985. Purification of cachectin, a lipoprotein lipase-suppressing hormone secreted by endotoxin-induced RAW 264.7 cells. J. Exp. Med. 154:631-639.

36. Feingold, K. R., and C. Grunfeld. 1987. Tumor necrosis factor-alpha stimulates hepatic lipogenesis in the rat in vivo. J. Clin. Invest. 80:184-190.

37. Mann, C. J., F. T. Yen, A. M. Grant, and B. E. Bihain. 1991. Mechanism of plasma cholesteryl ester transfer in hypertriglyceridemia. J. Clin. Invest. 88:20592066.

38. Ulevitch, R. J., A. R. Johnston, and D. B. Weinstein. 1981. New function for high density lipoprotein. Isolation and characterization of a bacterial lipopolysaccharide-high density lipoprotein complex formed in rabbit plasma. J. Clin. Invest. 67:827-837.

39. Levin, J., and L. Cluff. 1965. Endotoxemia and adrenal hemorrhage in the adult. A mechanism for the Waterhouse-Friderichsen syndrome. J. Exp. Med. 121:247-260.

40. Salkowski, C., and S. Vogel. 1992. Lipopolysaccharide increases glucocorticoid receptor expression in murine macrophages. A possible mechanism for glucocorticoid-mediated suppression of endotoxicity. J. Immunol. 149:40414047. 